\title{
Analysis of the Relationship of Time Period with Waiting Time and Quality of Service with Patient Loyalty in Navy Marine Hospital Cilandak Jakarta, 2018
}

\author{
Arie Widiyasa ${ }^{1}$, DR.R.H Djadjang A,SH,Mkes ${ }^{2}$, Dicky Dewanto TR,SKM,MARS ${ }^{3}$ \\ Hospital Administration Magister, University of Respati Indonesia
}

\begin{abstract}
Hospitals are expected to provide health services that have optimal standards. It is an accountability effort for each hospital to be able to compete with other hospitals in order to get an attitude of consumer loyalty. Factors that often disrupt the performance of the hospital are related to service waiting time. Delays in handling are important issues in service delivery. Recently, many studies have produced negative effects on the impact of longer waiting times on customer satisfaction and loyalty. This will influence the quality of service. With disruption of customer satisfaction can lead to reduced attitudes of patient loyalty. Creating loyal customers is an important strategy rather than just satisfying and satisfying patients.
\end{abstract}

Objective : To know the characteristics of the patients of Mother and Children Health Poly of Rumkitalmar Cilandak Jakarta, Analyzing whether there is a relationship between Service Waiting Time and Patient Loyalty of Rumkitalmar Cilandak Maternal and Child Health Poly. Analyzing whether there is a relationship between Service Quality and Patient Loyalty of Rumkitalmar Cilandak Maternal and Child Health Poly. Analyzing whether there is a relationship between Waiting Time Service and Quality of Service together with Patient Loyalty of Health Poly of Maternal and Child Health Rumkitalmar Cilandak

Research Method: It is a stellar research with Structural Equation Modeling (SEM) program type LISREL software. Carried out in June - July 2018. In this study 300 samples were used.

Research results: It was found that longer waiting times and service quality had a strong correlation with patient loyalty $\left(R^{2}=0.85\right)$. This means that the description of patients' loyal behavior (dependent variable) is very dependent on waiting time and service quality (independent variables) as much as $85 \%$. The waiting time itself is significant $\left(\mathrm{R}^{2}=\right.$ 0.93 ) to the dependent variable. Service quality towards loyalty is significant T-Value 5.68 (t-value $>t$-tabel (1.96) $\alpha$ $0.05)$.

Key words : Waiting Time, Service Quality, Patient Loyalty

\section{INTRODUCTION}

Increasingly intense competition requires a service provider institution or service provider to always pamper consumers by providing the best service. Customers will search products in the form of goods or services from companies that can provide the best service to them. If the patient is satisfied with the experience of service consuming goods or services, it is the first step to make the customer loyal. Duration of Waiting Time of a Service is one indicator in Service Quality and Patient Satisfaction when getting health services. Waiting for service for a long time causes patient dissatisfaction, which in turn influences the patient's perception and loyalty to hospital services. If the hospital ignores the waiting time in its health services, the total quality of hospital services indirectly is considered unprofessional and may reduce patient and family patient satisfaction. A $5 \%$ increase in consumer loyalty can increase profits by $25 \%$ to $85 \%$, and a $60 \%$ increase in sales to new consumers is on the recommendation of customers who are loyal to the hospital. Cilandak Marine Naval Hospital (Rumkitalmar Cilandak) Jakarta is a level II Navy Hospital that serves TNI members as well as the general public, equipped with health care facilities 8 to 11 specialistic and subspecialty types of health services, research and education facilities, and supervisors of marine health, with 200 patient beds as inpatient facilities. From the evaluation of the initial picking test conducted by researchers through observations and interviews responding to several direct complaints regarding the patient's services for the Maternal and Child Health Poly, it turns out that most of the questions that were sent to the door of Health Poly for Maternal and Child Health were the lengths of waiting and 


\title{
International Advanced Research Journal in Science, Engineering and Technology
}

\author{
Vol. 5, Issue 10, October 2018
}

the counseling doctors arrived who are late. Patients queued very early, while the service began late. Patient loyalty may not be embedded and has not crystallized since the beginning utilizing the service thus the possibility of patients not yet interested in entrusting themselves fully to the services provided by the Rumkitalmar Cilandak Maternal and Child Health Section.

\section{LITERATURE REVIEW}

\section{Service Waiting Time}

The service waiting time is the patient's waiting time for the service starting from the arrival of the patient at the registration location of the patient, sending the medical record file to the destination clinic until getting the examination service. Waiting time is the time used by patients to get outpatient services and inpatient care from the registration site to enter the doctor's examination room. Patient waiting time is one of the potential components that causes dissatisfaction. Patients will consider poor health services if the illness does not heal, long queues, and health workers are not friendly even though they are professional (Sabarguna, 2008).

\section{Quality of health services}

The quality of service or quality of health services is the level of perfection of health services carried out in accordance with the code of ethics and standard of service set, giving rise to satisfaction for each patient (Ministry of Health in Muninjaya 2014).

The quality dimension according to Parasuraman, consists of five dimensions, namely physical evidence (tangibles), service quality can be felt directly to the appearance of physical facilities and support in service, reliability, namely the ability to provide timely and accurate services as specified, power responsiveness, namely the willingness of officers to provide fast service according to procedures and able to meet customer expectations, assurance, which is associated with a sense of security and patient comfort because there is trust in officers who have the right competence, credibility and skills in providing services and patients get guaranteed safe and comfortable services, empathy, which is related to the care and attention of officers to each customer by listening to complaints and understanding needs and providing convenience for all customers in contacting officers.

\section{Patient Loyalty}

Consumers loyalty is a consumer belief in a product or service that is used, then consumers feel the level of satisfaction with the product or service. Often buy or use these products, and feel lost when moving to another product (even if for reasons of price and quality or product), and respecting the product and also defending the products they use or use (even though other products have quality and prices almost the same).

The dimensions of customer loyalty according to Baloglu (2002) are: Trust. This aspect is a customer confidence response to the company, Psychological (Emotion) Commitment. This aspect is the patient's psychological commitment to the company, Switching Cost. This aspect is the customer's response about the burden received when a change occurs, Word of mouth. This aspect is the publicity behavior carried out by customers towards the company, Cooperation. This aspect is customer behavior that shows the attitude of being able to work with companies.

\section{Relationship between Variables and Development of Hypotheses}

The ability to provide quality services in this case such as waiting times that can quickly meet patient expectations is a very important strategy to achieve competitive advantage. Zeithaml et al. (1996) stated that improving service quality can improve favorable behavioral intentions and reduce unfavorable behavioral intentions. Companies must test the impact of the quality of their services on customer responses, including signs of repurchasing or communicating word of mouth.

Kotler and Keller (2010) Quality is the overall features and properties of a product or service that influence its ability to satisfy expressed or implied needs. Patient waiting time is one of the potential components that causes dissatisfaction. Patients will consider poor health services if the illness does not heal, long queues, and health workers are not friendly even though they are professional. If the performance is below expectations, the customer feels dissatisfied. If performance meets expectations, customers are satisfied. If performance exceeds expectations, customers are very satisfied or happy. If customers feel satisfied, customers will be loyal to the product / service they use. If the customer is loyal, the customer will make a repeat purchase of the product and will convey positive things to the product to others. According to the research carried out by Wharton Business School, This improvement effort will make customers more loyal to the company. The concept of service quality and loyalty is related to one another. Theoretically, in the process can provide a reference to this study, where the quality of service or service quality affects loyalty both directly and affect loyalty indirectly through customer satisfaction (Dwi, 2010). 


\section{International Advanced Research Journal in Science, Engineering and Technology}

Vol. 5, Issue 10, October 2018

\section{Research Hypotheses.}

H1: There is a positive correlation between the length of waiting time and patient loyalty at the Cilandak Rumkital Marine Marternal and Child Jakarta.

$\mathrm{H} 2$ :There is a positive correlation between Service Quality and Patient Loyalty in Cilandak Rumkital Marine Maternal and Child Jakarta.

H3:There is a positive correlation between the duration of waiting time and the quality of service, together with the patient loyalty health poly of Cilandak Rumkital Marine Maternal and Child Jakarta.

\section{Research Method}

The selection of samples in this study used a random sampling method that is random sampling of $10 \%$ of the population. If the research is descriptive, it generally requires a large sample). Therefore the writer used the sampling technique formulated by Hair et al. (2010) who recommend a sample size of at least 100-200 observations depending on the number of indicators estimated. Testing of the research model with many variables was done using Structural Equation Modeling (SEM) type of LISREL software in which samples ranged from 150-400 (Sekaran, 2004). In this study 300 samples were used, thus they were sufficient. If more than 400 LISREL samples will be very sensitive (Hisham, 2009). . The collected data was then carried out Likert scale on a scale of one to five.

\section{Structural Equation Model (SEM).}

Table 5.1 : Analysis of Goodness of Fit

\begin{tabular}{|c|c|c|c|c|}
\hline Group & Indicator & Value & Standar & Ket \\
\hline \multirow[t]{4}{*}{1} & Degree of Freedom & 75 & & \multirow{4}{*}{ Good fit } \\
\hline & Chi Square & $110.78(0.0046)$ & $<111.92(0.0037)$ & \\
\hline & $\mathrm{NCP}$ & 36.92 & & \\
\hline & NCP Confidence Interval & $(12.46 ; 69.35)$ & & \\
\hline \multirow[t]{3}{*}{2} & RMSEA & 0.041 & $<0.08$ & \multirow{3}{*}{ Close fit } \\
\hline & $90 \%$ Confidence Interval & $(0.024 ; 0.056)$ & & \\
\hline & P Value & 0.84 & & \\
\hline \multirow[t]{4}{*}{3} & ECVI Model & 0.68 & & \multirow{4}{*}{ Good fit } \\
\hline & ECVI Saturated & 0.80 & & \\
\hline & ECVI Independence & 68.53 & & \\
\hline & Confidence Interval & $(0.59 ; 0.78)$ & & \\
\hline \multirow[t]{5}{*}{4} & AIC Model & 201.92 & & \multirow{5}{*}{ Good fit } \\
\hline & $\begin{array}{l}\text { AIC Saturated } \\
\text { AIC Independence }\end{array}$ & $\begin{array}{l}240.66 \\
20491.80 \\
\end{array}$ & & \\
\hline & CAIC Model & 413.59 & & \\
\hline & CAIC Saturated & 804.45 & & \\
\hline & CAIC Independence & 20562.36 & & \\
\hline \multirow[t]{6}{*}{5} & NFI & 0.99 & $>0.90$ & \multirow{6}{*}{ Good fit } \\
\hline & CFI & 1.00 & $>0.90$ & \\
\hline & NNFI & 1.00 & $>0.90$ & \\
\hline & IFI & 1.00 & $>0.90$ & \\
\hline & RFI & 0.99 & $>0.90$ & \\
\hline & PNFI & 0.71 & $0.6-0.9$ & \\
\hline 6 & Critical N & 288,16 & & Good fit \\
\hline \multirow[t]{4}{*}{7} & Standardized RMR & 0.015 & $<0.05$ & \multirow{4}{*}{ Good fit } \\
\hline & GFI & 0.95 & $>0.90$ & \\
\hline & AGFI & 0.92 & $>0.90$ & \\
\hline & PGFI & 0.60 & $0.6-0.9$ & \\
\hline
\end{tabular}

Source: test results of SEM

\section{Results and Discussion}

The instruments used in this study have been tested in validity and reliability thus the results obtained Construct Reliability and Variance Extracted WT of VE value 0.84, MP value VE, 0.80, LP value VE 0.78, goodness of fit, where Chi Square $=110.78$ Degree of Freedom $=75$, ECVI = 0.68, AIC =201.92, CAIC =413.59, Critical N = 288,16, RMR $=0.015$ and PGFI $=0,60$. Furthermore, this research produced a value diagram as shown in the following figure: 


\section{International Advanced Research Journal in Science, Engineering and Technology}

Vol. 5, Issue 10, October 2018

Path Diagram T-Value

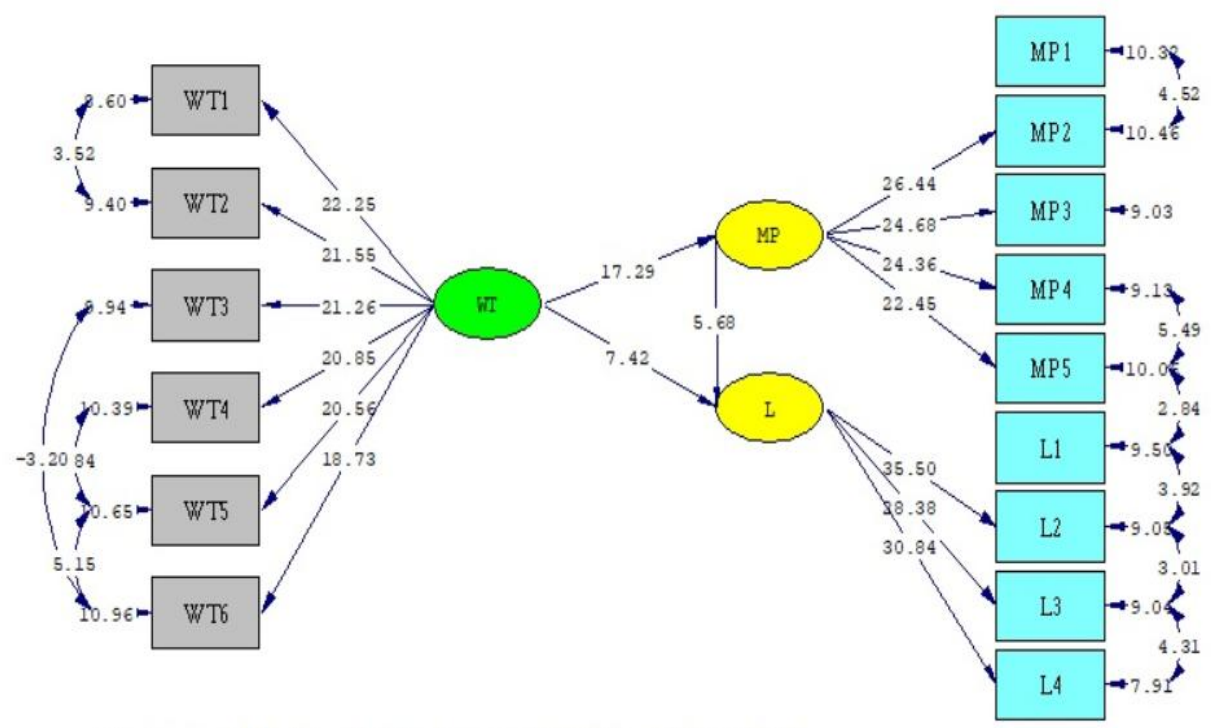

Chi-Square $=111.92, d f=75, p$-value $=0.00370$, RMSEA $=0.041$

Figure 5.2 Path Diagram T-Value

Table 5.2 : Hypothesis Testing of Research Model

\begin{tabular}{|l|l|l|l|}
\hline & \multicolumn{1}{|c|}{ Hypotheses } & T-Value & \multicolumn{1}{|c|}{ Note } \\
\hline $\mathrm{H}_{1}$ & $\begin{array}{l}\text { There is a positive correlation } \\
\text { between the length of waiting time } \\
\text { for patient loyalty }\end{array}$ & 7,42 & $\begin{array}{l}\text { Significant data supports } \\
\text { the hypothesis }\end{array}$ \\
\hline $\mathrm{H}_{2}$ & $\begin{array}{l}\text { There is a positive correlation } \\
\text { between the Length of Waiting } \\
\text { Time for Quality of Service }\end{array}$ & 17,29 & $\begin{array}{l}\text { Significant data supports } \\
\text { the hypothesis }\end{array}$ \\
\hline $\mathrm{H}_{3}$ & $\begin{array}{l}\text { There is a positive correlation } \\
\text { between Service Quality and Patient } \\
\text { Loyalty }\end{array}$ & 5,68 & $\begin{array}{l}\text { Significant data supports } \\
\text { the hypothesis }\end{array}$ \\
\hline
\end{tabular}

Source: Test results on data analysis tools

Duration of Waiting significantly positively correlated with Patient Loyalty.

In the results of testing the first hypothesis (H1), it was found that the results of the analysis support hypothesis $\mathrm{H} 1$, namely quick waiting time associated will increase patient loyalty ( $\mathrm{T}$-Value $7.42>\mathrm{T}$ table 1.96 , level sig $\alpha 0.05$ ). This illustrates that patient loyalty is influenced by the waiting time that matches the criteria. Good or quick waiting time can increase Patient Loyalty, and vice versa Patient Loyalty increases influenced by waiting time for patients who are not long. These results indicate that the patient's Long Service Time at Rumkitalmar Cilandak Maternal and Child Health Poly significantly affected the Loyalty behavior of Patients who went to Rumkitalmar Cilandak Outpatient and Maternal Health Section.

As a military hospital that is friendly to civilian patients and general patients, the risk of conflict is certainly high. Here, wise management is needed to deal with patients but firmly enforces the rules for all internal members of the hospital to comply with the rules and if they violate there will be consequences. According to Sabarguna (2008), a service that is carried out requires the existence of a service standard made in order to achieve goals such as achieving an increase in the size of the target service quality reciprocally will be achieved efficiently, either orally or in writing.

Regarding the Length of Waiting Time, Relationship with Quality of Service, it was found that the results of the analysis of the ideal factor of the Waiting Time will significantly improve Service Quality. T-Value 17,29 ( > T table 1.96 , level sig $\alpha 0.05$ ). This shows that the short duration of waiting time has a significant effect on the quality of service received by patients. Good or quick waiting times can improve service quality, and vice versa Quality services that increase can be affected by waiting times for patients that are quick or good.

For all officers or employees should serve patients with friendliness, dexterity and responsiveness to everything the patient wants. If the officer provides the best service, the quality of service can be achieved properly so that the patient is satisfied and eventually the patient will be loyal to the service provider. 


\section{International Advanced Research Journal in Science, Engineering and Technology}

Vol. 5, Issue 10, October 2018

Finally, the reputation of an agency will increase to be better in the eyes of the community and comunity trust can be achieved. Waiting time and touch time is an interrelated unit when the patient arrives.

\section{Quality of Service has a significantly positive correlation with Patient Loyalty.}

In the results of testing the third hypothesis $(\mathrm{H} 2)$, it was found that the results of the analysis supported hypothesis $\mathrm{H} 2$, namely good service quality increased patient loyalty by 5.68. From the results of this test it is shown that the quality of service has an effect on patient loyalty.

It is seen from Path Diagram T. Value that Service Quality in this study used 5 dimensions, including: Tangible (MP1), Reliability (MP2) amounting to 26,44, Responsiveness (MP3) amounting to 24,68, Assurance (MP4) amounting to 24,36 and Emphaty (MP) amounting to 22,45. These dimension values show that Reliability Service Quality has the highest value on Patient Loyalty. This can be interpreted that the Service Quality of Rumkitalmar Cilandak Maternal and Child Health Poly officers is able to have and present the ability to carry out the promised services reliably and accurately. This means a level of reliability in the eyes of the customer, including the ability to deliver promised services promptly, accurately, and satisfactorily, which includes managing patients from waiting to completion of receiving services.

The results of services that are correct or can be said according to what the patient needs, can certainly make patients feel comfortable and safe in undergoing treatment at Rumkitalmar Cilandak thus they can make patients more loyal. In addition to the delivery of promised services immediately, accurate service by hospital staff in work can minimize or even cause complaints from patients. This can make patients not hesitate to reuse Rumkitalmar Cilandak services for treatment or it can be said as an attitude of loyalty that has been formed. . Guilitnan (1997) suggested that one of the benefits of customer satisfaction is that it can increase customer loyalty.

The results of this study further corroborate the results of previous studies conducted by Wu (2015), which said that there was an effect of Service Time as one indicator of the Quality of Health Services on attitudes and behavior of Patient Loyalty.

Waiting Time and Service Quality together have a significantly positive correlation with Patient Loyalty. The $\mathrm{R}^{2}$ value serves to show how far the independent variable is able to explain the dependent variable. The results that can be analyzed are first, the effect of WT (waiting time) affects MP (Service Quality) with $\mathrm{R}^{2}$ of 0.85 . This means that $0.85 \%$ of the variant of MP (Quality of Service) can be explained by the variable WT (Waiting Time), while the remaining $15 \%$ can be explained by other variables not found in this study..

The second analysis was MP (Service Quality), Waiting Time (WT) has an effect on LP (Patient Loyalty) with $\mathrm{R}^{2}$ of 0.93 . This means that $93 \%$ of the variants of LP (Patient Loyalty) can be explained by the MP variable (Quality of Service), WT (Waiting Time), while the remaining 7\% can be explained by other variables not found in the study ini.

The duration of service is very important because in modern society time is a commodity that cannot be repeated again. Patients coming to the hospital need a long time to stand in line to be examined by a doctor, then in the process of taking the medicine starting from the prescription to the pharmacy until the patient receives the medicine that has been formulated or taken, it is expected that the patient will not wait too long. Past experience of patients about health services has an effect on the decision to choose or use the service in the future. In addition, this also affects other people who want to use the same services because recommendations from other people are usually quickly accepted as a reference for choosing a health service place.. If the patient already has a sense of belonging and has a good emotional bond with the hospital, usually he does not want to move to be treated in another hospital, even though there is a price change at the hospital. They already feel comfortable, trust and sympathy with the hospital and will easily promote the hospital to family and others. This indirectly has a positive impact on the hospital. Hospitals must improve their services, time of patient registration, time of treatment, time to terminate treatment, thus what the patient hopes will be fulfilled. This is understandable because the characteristics of people seeking treatment are different from those of healthy people, sick people need fast service in all aspects of service. Thus, it can be said that the effectiveness of service time will determine patient loyalty in the long run.

The same thing was stated by Lovelock and Wright (2005), which stated that there needs to be a match between medical services provided with what is needed from time to time. If all services provided have not been able to satisfy patients, this will end in low patient loyalty.

\section{CONCLUSION AND SUGGESTIONS}

\section{Conclusion}

The results of this study are expected to be useful for the policy of Rumkitalmar Cilandak Hospital which supports patient loyalty at Rumkitalmar Cilandak Hospital. Based on the research, the researchers concluded that: (i) Obtained a meaningful relationship between the duration of waiting time with patient loyalty. The impact of the length of waiting time is the time the patient is wasted while waiting for services, especially for official patients or patients who are escorted by their families who are active personnel. Of course the impact of the time wasted waiting will harm the 


\title{
International Advanced Research Journal in Science, Engineering and Technology
}

\author{
Vol. 5, Issue 10, October 2018
}

official. Patient and family satisfaction with health services will decrease and cause the behavior of patient loyalty to Rumkitalmar Cilandak will decrease. It is seen from the results of T-Value amounting to 7,42 although significant (> TValue table 1,96 $\operatorname{sig} \alpha 0.05)$ but not as strong as the relationship of Length of Waiting Time with Quality of Service $(17,29)$. This means that the variable of Length of Waiting Time more strongly affects Service Quality compared to Patient Loyalty attitudes (ii) Service Quality has a significant positive correlation with Loyalty of Patients who check themselves out to Rumkitalmar Cilandak Maternal and Child Health Poly (T-Value 5.68> T-Value table 1.96 sig $\alpha$ 0.05). Service quality is one of the determinants of the behavior of patients being loyal to this hospital, but if the service provided is not in accordance with the expectations of the patient, it will cause the quality provided to be not optimal. The services provided are all in a hurry causing the implementation stage not in accordance with the standard rules (SOP). The risk of sacrificing patient safety is easy. Patient's loyal behavior is not formed thus patients will not prioritize the hospital as an alternative choice of place to solve the problems they havea. (iii) The variable of Length of Waiting Timeand and Service Quality variable is positively correlated with Loyalty of Patients who examined themselves at Rumkitalmar Cilandak Maternal and Child Health Poly $(\mathrm{R} 2=0.93)$. This is stronger than just the Service Quality variable $(\mathrm{R} 2=85)$. Both of these independent variables together cause an increase in loyal behavior of patients.

\section{Suggestions}

In order to create attitudes and shape loyal behavior of patients visiting Rumkitalmar Cilandak Maternal and Child Health Poly, it is necessary to create optimal perceptions regarding the performance of health services from the Maternal and Child Health Poly starting from Rumkitalmar Cilandak outpatient registration system to Maternal and Child Health Poly, some suggestions include: (i) For Characteristics of Respondents, the provision of better and more modern hospital facilities and infrastructure. Like the availability of an independent registration platform connected to the medical record system, the patient's waiting room is made comfortable and adequate. Because patients with Health Poly of Maternal and Child are women, there is a need for ASI Corner Rooms. Adequate toilet facilities, for front line personnel (before medical services by counselors) are expected to be very empathetic to the problems facing patients and to know the ins and outs of the hospital so that patients are informed from the start. Strive for regular and continuous training and debriefing because even though training has been carried out, there are still complaints of patient dissatisfaction. (ii) For the Duration of Service with Patient Loyalty, the application of digitization in line at the time of service can help patients measure the time available for patients. Patients can use the available time effectively and efficiently, Need fast, precise and continuous coordination between units (poly-patient status registration), Reevaluate brainstorming routines and innovate looking for the most effective and efficient methods. (iii) For Quality of Service with Patient Loyalty, regular and multi-level training on a regular basis, to consul physicians, is done credentially again to find out the commitment to the hospital and its programs, conduct internal trainings. (iv) For the Duration of Waiting Time and Service Quality together with Patient Loyalty, striving to optimize the service program received by patients from all sides, facilitating registration, making it comfortable while waiting for services, involved personnel empathizing with the patient's condition and responsive and agile.

\section{REFERENCES}

[1]. Administrasi Medis RSMC. "Data kunjungan Poli KIA RSMC tahun 2017 dan 2018”. Januari 2018

[2]. Administrasi Bagian KIA. "Pelaporan Triwulan I, II, III dan IV tahun 2017 Poli KIA RSMC". Januari 2018.

[3]. Aditama T. "Distribusi Waktu Tunggu pada Antrian dengan Menggunakan Disiplin Pelayanan Prioritas (Studi Kasus: Instalasi Rawat Darurat di RSUD Dr. Soetomo Surabaya)". Jurnal Sains dan Seni Pomits 2013;1(1) : halaman 1-6.

[4]. Arieta R. "Analisis Waktu Tunggu Pasien di Departeman Gigi dan Mulut RSPAD Gatot Soebroto Ditkesad Tahun 2011". Fakultas Kesehatan Masyarakat (Tesis). Jakarta: Program Studi Kajian Administrasi Rumah Sakit Universitas Indonesia; 2012

[5]. Ali Abdolvand, Muhammad dan Abdollah Norouzi. 2012. "The Effect of Customer Perceived Value on Word of Mouth and Loyalty in B-2-B Marketing”. Research Journal of Applied Sciences, Engineering and Technology 4(23): 4973-4978.

[6]. Dwi Aryani Dan Febrina Rosinta. "Pengaruh Kualitas Layanan Terhadap Kepuasan Pelanggan Dalam Membentuk Loyalitas Pelanggan. Bisnis dan Birokrasi”. Jurnal Ilmu Administrasi dan Organisasi, Mei-Agustus 2010, hlm.114-126, ISSN 0854-3844.

[7]. Esti A. "Pengaruh Waktu Tunggu dan Waktu Sentuh Pasien terhadap Tingkat Kepuasan Pasien Poli Umum di Puskesmas Sukorame Kota Kediri". Publikasi.Stikesstrada.ac.id/wpcontent/uploads/2015/02/8. pdf. 2012.

[8]. Neti M Bustani, A Joy Ratu. "Analisis Lama Waktu Tunggu Pelayanan Pasien Rawat jalan di Balai Kesehatan Mata Masyarakat Propinsi Sulawesi Utara". Jurnal e-Biomedik(eBm), volume 3, nomor 3. September-Desember 2015.

[9]. Nur Laeliyah, 2016. "Hubungan Waktu Tunggu Pelayanan Rawat Jalan dengan Kepuasan pasien terhadap pelayanan di rawat jalan RSUD Kabupaten Indramayu". Publikasi medis.

[10]. Oey Hannes Widjaya, 2014. "Analisa pengaruh waktu tunggu, harga dan kualitas terhadap kepuasan pelanggan dan loyalitas pelanggan R seafood". Publikasi umum.

[11]. Parasuraman, A., Valarie A. Zeithami dan Leonard L. Berry. 1985. “A Conceptual Model of Service Quality and Its Implications for Future Research". Journal of Marketing 49: 41-50.

[12]. Sulistiyorini C, Lestari T, Rohmadi. "Tinjauan faktor penyebab waktu tunggu pelayanan pendaftaran pasien umum rawat jalan di RSUD Sragen". Studi Rekam Medis. 2012; 6 (2).

[13]. Torry. 2016. "Faktor yang mempengaruhi waktu tunggu pelayanan kesehatan kaitannya dengan kepuasan pasien rawat jalan Klinik Penyakit Dalam RSUD dr. Iskak Tulungagung”. Publikasi medis. 